\title{
Isolation and Genetic Characterization of Bacteria Associated with Philaenus spumarius for the Control of Xylella fastidiosa ${ }^{\dagger}$
}

\author{
Ana Afonseca *, Sofia Silva, Cristina Cameirão (D) and Paula Baptista \\ Centro de Investigação de Montanha (CIMO), Instituto Politécnico de Bragança, Campus de Santa Apolónia, \\ 5300-253 Bragança, Portugal; sofiasilva-99@hotmail.com (S.S.); ccameirao@ipb.pt (C.C.); pbaptista@ipb.pt (P.B.) \\ * Correspondence: anafilipa.afonseca53@gmail.com \\ † Presented at the 1st International Electronic Conference on Plant Science, 1-15 December 2020; Available online: \\ https://iecps2020.sciforum.net/.
}

check for updates

Citation: Afonseca, A.; Silva, S.; Cameirão, C.; Baptista, P. Isolation and Genetic Characterization of Bacteria Associated with Philaenus spumarius for the Control of Xylella fastidiosa. Biol. Life Sci. Forum 2021, 4 , 14. https://doi.org/10.3390/ IECPS2020-08859

Academic Editor: Yoselin

Benitez-Alfonso

Published: 2 December 2020

Publisher's Note: MDPI stays neutral with regard to jurisdictional claims in published maps and institutional affiliations.

Copyright: (c) 2020 by the authors. Licensee MDPI, Basel, Switzerland. This article is an open access article distributed under the terms and conditions of the Creative Commons Attribution (CC BY) license (https:// creativecommons.org/licenses/by/ $4.0 /)$.

\begin{abstract}
The endosymbiotic bacteria that live within the body of insects are involved in many aspects of the host physiology, including reproduction and defense. Thus, the exploitation of these microorganisms may have practical applications for the management of vector-borne diseases. In the Mediterranean area, Philaenus spumarius was identified as the main vector of Xylella fastidiosa. This xylem-restricted bacterium is responsible for several diseases in a variety of agricultural crops of high importance, for which there are not any effective control methods. Thus, in this work we evaluate different media types for the isolation and growth of bacteria living within $P$. spumarius adults, for their potential exploitation in the management of X. fastidiosa. Specifically, we compared the effect of minimal (Luria Bertani-LB) and complex (Modified Melin-Norkrans-MMN) media, with and without fetal bovine or gelling agents, on the number and diversity of bacteria. The collection of isolates obtained was further genetically characterized by repetitive element-based PCR method (BOX-PCR) and sequencing of the $16 \mathrm{~S}$ ribosomal RNA (rRNA) gene. The results showed no significant differences in the abundance and diversity of bacteria among the two media tested (LB and MMN). The addition of fetal bovine to the media leads to a slight increase in bacterial abundance, in particular in MMN medium. While the liquid media led to a significant increase in abundance, the solid media facilitated the growth of more diverse bacterial taxa. The comparison between BOX-PCR and 16S rRNA gene sequencing for the analysis of 57 bacterial isolates revealed a greater discriminatory power of the former, allowing the differentiation of the bacteria even at the intra-species level. The clustering of the isolates using BOX-PCR fingerprinting was different to that obtained from the 16S rRNA gene phylogenetic tree. The 16S rRNA gene sequencing method proved to be more suitable in phylogenetic evaluations, generally grouping isolates belonging to the same genus.
\end{abstract}

Keywords: culture media; DNA fingerprinting; BOX-PCR; 16S rRNA gene sequencing

Supplementary Materials: The poster presentation is available online at https: / www.mdpi.com/ article/10.3390/IECPS2020-08859/s1.

Acknowledgments: This work has received funding from the European Union's Horizon 2020 research and innovation programme under Grant Agreement N. 727987 “Xylella fastidiosa Active Containment Through a multidisciplinary-Oriented Research Strategy XF-ACTORS". 